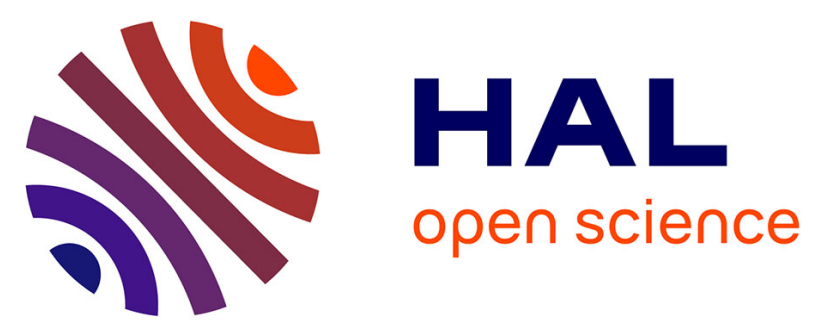

\title{
Asphaltenes diffusion/adsorption through catalyst alumina supports - Influence on catalytic activity
}

Bertrand Guichard, Florine Gaulier, Jérémie Barbier, Thibaut Corre, Jean-Louis Bonneau, Pierre Levitz, Didier Espinat

\section{To cite this version:}

Bertrand Guichard, Florine Gaulier, Jérémie Barbier, Thibaut Corre, Jean-Louis Bonneau, et al.. Asphaltenes diffusion/adsorption through catalyst alumina supports - Influence on catalytic activity. Catalysis Today, 2018, 305, pp.49-57. 10.1016/j.cattod.2017.10.016 . hal-01855384

\author{
HAL Id: hal-01855384 \\ https://hal.science/hal-01855384
}

Submitted on 7 Aug 2018

HAL is a multi-disciplinary open access archive for the deposit and dissemination of scientific research documents, whether they are published or not. The documents may come from teaching and research institutions in France or abroad, or from public or private research centers.
L'archive ouverte pluridisciplinaire HAL, est destinée au dépôt et à la diffusion de documents scientifiques de niveau recherche, publiés ou non, émanant des établissements d'enseignement et de recherche français ou étrangers, des laboratoires publics ou privés. 


\title{
ASPHALTENES DIFFUSION/ADSORPTION THROUGH CATALYST ALUMINA SUPPORTS - INFLUENCE ON CATALYTIC ACTIVITY
}

Bertrand Guichard $^{l^{*}}$, Florine Gaulier ${ }^{1}$, Jérémie Barbier ${ }^{1}$, Thibaut Corre ${ }^{1}$, Jean-Louis Bonneau ${ }^{1}$, Pierre Levitz ${ }^{2}$, Didier Espinat ${ }^{1}$

${ }^{1}$ IFP Energies nouvelles-Lyon, Rond-point de l'échangeur de Solaize, BP 3,69360 Solaize, FRANCE

${ }^{2}$ Laboratoire PHENIX, Université Pierre et Marie Curie, 4 place Jussieu, 72522 Paris Cedex 5, FRANCE

\author{
* Corresponding author: \\ Email: bertrand.guichard@ifpen.fr \\ $+33437702308$
}

Keywords: Asphaltenes, Diffusion, Adsorption, Catalyst, Hydroprocessing, Reactivity 


\section{ABSTRACT}

Refining heavy or extra heavy oil is still an important challenge for petroleum chemistry. The research performed in the field of hydroprocessing technologies covers different sides of the domain laying from the reactor and process aspects to heterogeneous catalysts development. Historically, at a large scale of time, the worldwide trend seems to indicate a decline of light conventional crude oil availability, the latest being gradually replaced by heavier nonconventional resources that contain asphaltenes and high concentrations of nitrogen and sulfur compounds. It emphasizes the need for conversion of the heaviest feeds and for improving the corresponding refining catalysts. One point raised here to progress deals with the role of the support (alumina), peculiarly about the role of the nanoporous texture on the accessibility of the feedstock molecules to the active sites. Among these large molecules to be considered, asphaltenes play a major role and are often pointed out to be responsible for the industrial issues: plugging porosity, coking support and metal sulphide active phase, poisoning hydrogenating metal. The macrostructure of asphaltenes is complex, characterized by a multi-scale aggregation behavior, strongly influenced by environmental parameters, as for instance the temperature. We have tried in this contribution to confront the abilities of various monomodal and bimodal alumina supports to let asphaltenes diffuse and adsorb into their porosity. An experimental device dedicated to assess the diffusion and adsorption of carriers has been used. The influence, on the mass transfer and the penetration depth, of various parameters such as temperature, asphaltene concentration of the solution, and alumina porous texture was appraised. It is clearly shown that extrudates requires several days do reach an equilibrium, suggesting a very low diffusion kinetic. The diffusion kinetic can be speed-up using an adapted support, especially with high pore diameter and macroporous pores but even if the extrudates of macroporous support 
might be likely to adsorb till its chemical saturation, i.e. an asphaltene content equal to 1.4 $\mathrm{mg} / \mathrm{m}^{2}$ consistent with previous publications for those species. As a consequence, NiMoP-B14 is the best catalyst for all the reactions reaching $50 \%$ of gain for $\mathrm{HDAsC} 7$ and $40 \%$ in HDV. It highlights a clear link is established between catalytic performances and diffusion and could be usefull for designing the best carriers to be used in heavy feed hydrporocessing.

\section{INTRODUCTION}

Historically over a large scale of time, the worldwide trend seems to indicate a decline of light conventional crude oil availability, the latest being gradually replaced by heavier nonconventional resources that contain high concentrations of nitrogen and sulfur compounds and metals like vanadium and nickel. Those compounds are known to be very difficult to characterize. To do so, the heaviest fraction of the petroleum residues is separated by precipitation using paraffins, for instance the $n$-heptane. This fraction is called asphaltenes [1]. The structure of the asphaltenes is a subject of much controversy [2-8], but it is accepted that they are rather large molecules that concentrate the impurities. The large size and the possible colloidal structure will make hydrotreatment harder when compared to lighter structures.

The associated specific refining operation consisting in transforming heavier petroleum feedstocks into products with more added value is named conversion and consists in the transformation of heavy compounds, i.e. boiling at temperature higher than $813 \mathrm{~K}$ (Vacuum Residue) or higher than 643K (Atmospheric Residue) into lighter ones, i.e. boiling at lower temperature (transportation fuels). In parallel, stringent regulation and speciation on polluting agent in fuels (like sulfur compounds) highlights the need of improve the existing processing 
yield and the final quality of products. It means that the catalytic active phase need to be optimized, i.e. catalytic active phase needs to be well dispersed, as it is aimed usually in catalytic hydrotreating [9-17]. It requires tremendous effort to optimize the active phase, but when one deals with heavy petroleum feed to be hydrotreated, it is also essential to take into account the accessibility to active phase adjusting the mesoporous alumina support.

From the industrial point of view, many heterogeneous catalysis processes need to use catalysts shaped as pellets or extrudates and sufficiently large, essentially in order to reduce the reactor pressure drop $[\mathbf{1 8 , 1 9 ]}$. This is even more necessary concerning fixed bed residue hydrotreating units where pressure drop is one of the first criteria to be taken into account. As a consequence, the catalytic activity is often related to the support effects and indirectly to a more specific active phase provided by metal sulphides [20, 21]. An active field of investigation aims to elucidate the cause of this deactivation which is still a challenge for catalyst manufacturers [22].

The following contribution deals with hydrotreatment catalysis especially the one dedicated to those large refractory compounds, the asphaltenes. Recently proposed models depict asphaltenes as a multi-scale colloidal system, where free various types of molecules, from the point of view of chemical composition, are in equilibrium with nanoaggregates and much larger fractal clusters made by the aggregation of several nanoaggregates [6]. This asphaltene description prompts some diffusion limitations through the catalytic porous network and clearly established that the temperature has a tremendous influence on the aggregation state of asphaltenes [23]. The influence of the pore size distribution of the alumina support was asserted a long-time ago [24]. Afterwards, many works were launched in the literature about the characterization of transport properties of different size molecules through the catalytic porous network, but with rather few 
papers assessing the fundamental diffusion aspects and the catalytic operation of materials. Some contributions tackled the asphaltene diffusion through specific porous membranes [25-29]. The basic principle of these experiments consists in using various types of cells, as for instance the Wicke-Kallenbach-type diffusion cell. These studies enable to assess the asphaltene diffusion coefficient and the size of asphaltene. In some cases, model molecules were also used to assess the diffusion limitations [30]. Other contributions dealt with catalytic solids [31-38]. A more recent strategy previously detailed was proposed in order to cope with the temperature effect on diffusion process [39]. From the experimental data giving asphaltene concentration versus time and using diffusion and adsorption models, it was possible to deduce some key parameters as the average size of the molecules, the diffusion coefficient and some parameters characteristic of the adsorption [32-34].

This paper gathers experimental results on the asphaltenes transport into various catalytic supports used for refining catalytic hydrotreatments. The methodology is based on the use of a new high temperature and pressure unit which was previously detailed in a recent contribution aforementioned [39]. Alumina supports are put in contact with asphaltenes dispersed in toluene and their penetration through the porosity is followed versus time by ex-situ analysis. Several parameters governing the diffusion are investigated as the temperature, the carrier textural properties, the initial surrounding asphaltene concentration. Finally, catalytic performances were discussed relatively to the diffusion/adsorption abilities.

\section{Materials and methods}

\subsection{Alumina supports and catalysts}


Four types of catalytic supports have been selected: three alumina supports with a meso singlemode pore size distribution centered respectively to 9,14 and $17 \mathrm{~nm}$ (respectively referred in the text M9, M14 and M17) and another type with both a meso and a macro pore size distributions respectively centered to 14 and $820 \mathrm{~nm}$ (referred as B14). The carriers are representative for the industrial one and can be considered as good witnesses of behavior that would be obtained industrially. The pore size distributions were measured by mercury porosity technique according to ASTM D4284-03 method and are shown in Figure 1 for M9, M14, M17 and B14. Other properties are summarized on Table 1. All the supports were cylindrical extrudates whose diameter is close to $3 \mathrm{~mm}$ and an average length of $10 \mathrm{~mm}$. Those carriers have been synthetized in lab according to published patent [40].

The corresponding catalysts, named NiMoP-M14, NiMoP-M17, NiMoP-B14 were obtained from the incipient wetness impregnation with a NiMoP solution into the previously mentioned supports. The solution containing $\mathrm{Ni}$, Mo and $\mathrm{P}$ was prepared under reflux at $90{ }^{\circ} \mathrm{C}$ using respectively $\mathrm{Ni}(\mathrm{OH})_{2}, \mathrm{MoO}_{3}$ and $\mathrm{H}_{3} \mathrm{PO}_{4}$ as precursors. Impregnation is followed by a maturation step in a water saturated atmosphere, for 24 hours at room temperature. Then, a drying step was performed for 24 hours at $120{ }^{\circ} \mathrm{C}$ followed by calcination under air for 2 hours at $450{ }^{\circ} \mathrm{C}$.

The target concentration of active phase for all catalysts is $9 \mathrm{wt} . \% \mathrm{MoO}_{3}$ with the following molar ratio $\mathrm{Ni} / \mathrm{Mo}=0.4$ and $\mathrm{P} / \mathrm{Mo}=0.5$. The $\mathrm{XRF}$ analysis reveals that the concentration is in agreement with the previous mentioned values. It has to be noted that NiMoP-M14 and NiMoPB14 do not exhibit the same quantity of molybdenum per surface area due to the fact that M14 and B14 carrier do not have the same surface area.

\subsection{Experimental diffusion set-up}


The detailed procedure of the diffusion experiments is described in a previous publication [39]. For performing experiments, asphaltenes were extracted by $\mathrm{n}$-heptane precipitation from a Safaniya vacuum residue and were further dissolved in toluene at the concentration of 2 wt $\%$. Alumina catalytic supports, without their active phase, were immersed in the asphaltene solution; the initial weight ratio of the amount of asphaltenes in solution to the catalytic supports was fixed to $360 \mathrm{mg} / \mathrm{g}$. In consequence, the asphaltene concentration of the surrounding solution was not rigorously constant during the experiments but keeps high enough to be in excess. A dedicated cell was developed to monitor temperature and pressure closed to industrial ones ( $523 \mathrm{~K}$ and 5 $\mathrm{MPa}$ ). The diffusion behavior is compared to the one at ambient conditions (293K and $0.1 \mathrm{MPa}$ ). After a contact time support-asphaltene solution, varying from few hours to several days, the catalytic supports were recovered from the asphaltene solution by filtration and then the supports, consecutively dried, and the asphaltene were submitted to various characterizations. A precise mass balance on asphaltenes was calculated and is closed to $90 \%+/-5 \%$, allowing the determination of the asphaltenes weight repartition between the solution and the support [39]. The molecular weight distribution of asphaltenes in solution was determined by Size Exclusion Chromatography (SEC). The penetration depth of the asphaltenes into the supports was followed by optical microscopy and the evolutions of the porosity of the supports were determined by nitrogen adsorption according to ASTM D3363-03 method.

The same apparatus is also used to assess the adsorption ability of the various carriers versus asphaltenes. To do so, extrudates were crushed between $100-210 \mu \mathrm{m}$. This size allows to estimate the adsorption contribution into the mechanisms diffusion/adsorption even if it is clearly not enough small to eliminate the diffusion contribution. But for experimental reason we did not 
use smaller fractions, the one being too much difficult to separate from the asphaltenes at the end of the experiment.

\subsection{Catalyst activation and evaluation (Vacuum resid)}

Before catalytic evaluation in batch reactor, the catalysts were sulphided in gas-phase at atmospheric pressure. Catalysts were introduced in a glass reactor and heated from room temperature to $350{ }^{\circ} \mathrm{C}$ at $5{ }^{\circ} \mathrm{C} \cdot \mathrm{min}^{-1}$ followed by 2 hours at this temperature, under a $15: 85 \mathrm{v} / \mathrm{v}$ $\mathrm{H}_{2} \mathrm{~S} / \mathrm{H}_{2}$ gas mixture flow at $2 \mathrm{NL} . \mathrm{g}_{\text {catalyst }}{ }^{-1} \mathrm{~h}^{-1}$. This gas flow insures a large excess of sulphur in relation to $\mathrm{MoS}_{2}$ stoechiometry. At the end of the sulfidation, the reactor was cooled down to room temperature and the $\mathrm{H}_{2} \mathrm{~S} / \mathrm{H}_{2}$ flow was replaced by argon flow up to 15 minutes. Afterwards, reduced pressure was applied into the glass reactor $(\sim 100 \mathrm{~Pa})$ and it was sealed to prevent the sample from reoxidation. This operation, in particular reduce pressure, is only applied to seal easily the glass cell and so to obtain a long term sample, catalytic evaluation being only carried out some days after sulfidation.

The composition of Safaniya Vacuum Residue (VR) is reported in Table 2. It contains large amounts of metals and asphaltenes (14 wt\%). The catalytic test was carried out in an isothermal stainless steel $300 \mathrm{~mL}$ batch reactor operated. The catalyst is introduced inside a stationary perforated basket with a hollow stirrer placed in the center. A catalyst volume of $20 \mathrm{~mL}$ (sulphided ex-situ) was used for treating $120 \mathrm{~mL}$ of feedstock. The reactor is first purged with hydrogen, then pressurized to $4.2 \mathrm{MPa}$ and heated up, from room temperature to the test temperature $(673 \mathrm{~K})$ at $13{ }^{\circ} \mathrm{C} \cdot \mathrm{min}^{-1}$, in a reproducible way. When temperature reaches to $373 \mathrm{~K}$, the hollow stirrer rotation is started up to $900 \mathrm{rpm}$ for temperature and composition homogenization, and for promoting the contact between gas-liquid phases. The pressure is generated by the temperature increase and is maintained constant during the test by a hydrogen 
make-up after adjusting at $14.5 \mathrm{MPa}$. The hydrogen consumption is determined by following the pressure drop in the make-up hydrogen tank. Reaction time is counted after 30 min passed heating and after pressure stabilization phase at $673 \mathrm{~K}$. From this moment, the catalytic test is performed for 3 hours (reaction time equivalent to $0.5 \mathrm{~h}$ contact time for 120:20 feed/catalyst volume ratio). At the end of the test, the reactor is cooled down using an air vortex system, reaching $423 \mathrm{~K}$ in $10 \mathrm{~min}$. The final product is recovered at $298 \mathrm{~K}$.

The remaining asphaltenes content in the final product is measured from $\mathrm{n}$-heptane precipitation according to NFT60-115 standardized method and Sulfur, vanadium and nickel are quantified by XRF. Carbon Conradson residue (CCR) measurements are also performed according to NF EN ISO 10370 standardized method. This measurement corresponds to the proportion of residue recovered after a pyrolysis of the sample and allows to indicate the tendency of an oil to make coke.

Conversions are compared using the following equation:

HDX $=\frac{m_{\text {feed }}[X]_{\text {feed }}-m_{\text {product }}[X]_{\text {product }}}{m_{\text {feed }}[X]_{\text {feed }}} \times 100 \quad$ Equation 1

Where $X$ stands for $\mathrm{AsC}_{7}$ asphaltenes, sulphur, $\mathrm{Ni}, \mathrm{V}$ or $\mathrm{CCR}$ concentrations in liquid effluent. $m$ stands for the feed mass $\left(\mathrm{m}_{\text {feed }}\right)$ or liquid effluent mass $\left(\mathrm{m}_{\text {product }}\right)$.

An ASTM D1160 normalized distillation is performed in order to obtain the distillation fraction which contains compounds with lower boiling temperatures than $643 \mathrm{~K}$ (also called $643 \mathrm{~K}^{-}$fraction) and the fraction containing the heaviest components which have boiling temperatures higher than $643 \mathrm{~K}$ (also called $643 \mathrm{~K}^{+}$fraction). Then simulated distillation on the liquid effluent allows us to calculated the percentage of naphtha (373-493K), gasoil (493-643K), 
vacuum gasoil (VGO, 643-813K) and vacuum residue (VR, $\left.813 \mathrm{~K}^{+}\right)$. More particularly, we will focus on the weight residue conversion calculated as:

$\chi_{813 \mathrm{~K}}^{+}(\%)=\frac{\left(X_{813 \mathrm{~K}^{+}}\right)_{\text {feed }}-\left(X_{813 K^{+}}\right)_{\text {product }}}{\left(X_{813 K^{+}}\right)_{\text {feed }}} \quad$ Equation 2

where $\left(\mathrm{X}_{813 \mathrm{~K}}{ }^{+}\right)_{\text {feed }}$ is the mass fraction boiling above $813 \mathrm{~K}$ in the feed and $\left(\mathrm{X}_{813 \mathrm{~K}}\right)_{\text {product }}$ is the mass fraction boiling above $813 \mathrm{~K}$ in the liquid product. Gas fraction is evaluated by the weight loss of the feed after test. Simulated distillation was performed on an Agilent Technologies chromatograph 6890N. Sample were diluted in $\mathrm{CS}_{2}$ and injected on a non-polar SimDist Ultimetal column $(0.53 \mathrm{~nm} \times 0.53 \mu \mathrm{m})$. Compounds were eluted by Argon as a function of their ebullated points and dosed by a FID detector.

\subsection{Textural properties characterization}

The porous distribution of supports was determined by mercury porosimetry using a Micromeritics Autopore IV 9520. The Kelvin law relating pressure and pore radius was applied. Moreover carrier had also been characterized by nitrogen adsorption isotherm using a Micromeritics ASAP 2420. BET and BJH methods were used [41] to calculate pore distribution and specific surface area.

\section{RESULTS AND DISCUSSIONS}

\subsection{Adsorption of asphaltenes.}

Before we can estimate the diffusion abilities of the various alumina carriers and discuss the impact on catalytic properties, we have tried to assess the maximum amount of asphaltenes which can be adsorbed on alumina supports as a function of the asphaltene concentration of the wetting solution. To do so, the experiment is performed on crushed extrudates (see experimental 
section). Figure 2 shows the adsorption isotherms at room temperature and at $523 \mathrm{~K}$. After very long exposition times a stationary regime with no variation of the asphaltene concentration of the solution is reached (between 7 and 14 days). Those steady values have been used here to build the isothermal adsorption trends. Despite a high affinity of asphaltenes regarding the alumina surface, as deduced from the tremendous increased of the adsorbed amount at low concentration into the surrounding solution $(<0.4 \mathrm{mg} / \mathrm{g})$, a maximum value is reached at higher concentration (> $10 \mathrm{mg} / \mathrm{g}$ ), corresponding to the saturation of surface alumina. According to the surface area the maximum uptake of each supports can be assessed (Table 3). It needs to be compared to the diffusion features that have been obtained (see in next part of discussion).

It worth to be noted that an increase of the temperature is followed by an increase of the asphaltene amount at saturation on the support $\left(0.84 \mathrm{mg} / \mathrm{m}^{2}\right.$ to be compared to $0.66 \mathrm{mg} / \mathrm{m}^{2}$, i.e. $27 \%$ higher). This observation is quite in contradiction with the classical behavior of adsorption where an increase of the temperature means a decrease of the adsorbed quantity. We can explain this result taking into account that the asphaltenes at high temperature have a much lower average molecular weight [23], which can speed up the diffusion process in comparison with the desorption behavior. It could be another way to confirm that the results obtained here are not only focused as expected onto the adsorption, but are still influenced by diffusion. In addition, the saturation could also be influenced by the plugging consecutive to the difficulties to transfer to the core of extrudates. Unfortunately the textural changes were not possible to be assessed in that case due to low amount of sample and this theory can not be supported.

It can also be proposed that asphaltenes at $523 \mathrm{~K}$ do not exhibit the same chemical affinity with alumina as at room temperature (293K) because of aggregation/disaggregation phenomena. 
Moreover, even if literature reports that depending on the chemical composition of the carrier 2 to 6 times more asphaltenes can be adsorbed $\left(1.5\right.$ to $\left.3.6 \mathrm{mg} / \mathrm{m}^{2}\right)$ [42-44], our results tend to underline that it is not possible to expect to reach those saturation values in realistic system like extrudates and real feeds containing classical amount of asphaltenes (from 2 to $20 \mathrm{wt} \%$ ). Indeed, the difference is too high and to reach those values it has been necessary to use a granulometry close to $0.3 \mu \mathrm{m}$. It suggests that with time contact or LHSV usually applied in the industry, the steady state and saturation is very difficult to reach.

\subsection{Diffusion of asphaltenes}

First, the diffusion of asphaltenes was studied with the support M14. As for adsorption experiments, at large contact time, more than 20 days, a steady amount is reached and is more or less in accordance with the maximum saturation reached during the adsorption experiments : 200 $\mathrm{mg} / \mathrm{g}$ at $523 \mathrm{~K}$ and $100 \mathrm{mg} / \mathrm{g}$ at room temperature for 1.6 and $1.0 \mathrm{wt} \%$ in the surrounding solution (Figure 3). We can suggest that the same phenomenon is observed here: there is a saturation at higher value at $523 \mathrm{~K}$ compared to RT. The textural properties of alumina after adsorption were compared for each experiment used to build the curve of Figure 3. No pore plugging seems to occur, even at very high amount of asphaltenes incorporated and $523 \mathrm{~K}$ (more than $100 \mathrm{mg} / \mathrm{g}$ ): Structural density remains the same and porosity / pore volume decrease according to a linear

tendency in agreement with an homogeneous deposit (Figure 4). The linear tendency is defined according to the asphaltene density $\left(\rho_{a s p h}\right)(1,22 \pm 0,12)$ and knowing the mass of asphaltenes on the support (see also reference [37] for this calculation):

$$
\varepsilon_{i}=\varepsilon_{a l}-\frac{\left(1-\varepsilon_{a l}\right) \cdot \rho_{a l} \cdot X_{i}}{\rho_{a s p}} \quad \text { Equation } \mathbf{3}
$$


Where $\rho_{a l}$ is the structural density of initial alumina support $(3.22+/-0.32), \varepsilon_{a l}$, its initial porosity $(68+/-4 \%)$ and $X_{i}$ is the asphaltene content in grams of asphaltenes per gram of alumina. For this model, we do not take into account any occlusion of the porosity giving rise to a simultaneous isolation of several pores.

One point significantly diverges from this behavior: the RT experiment during 84 days (porosity equal to 53\%). It suggests that at the end an occlusion mechanism starts, due to an important accumulation of asphaltenes, but it would start after reaching the saturation. This occlusion phenomenon was already observed on a very different situation but with a similar alumina support, during high temperature catalytic reforming when a dwindling catalytic activity by coking is observed [45].

It could mean that the difference of amount according to temperature is probably not due to intrinsic diffusion but could be mainly due to a difference in the chemical nature of asphaltenes and/or more probably to a difference in aggregation state that could have speed-up the diffusion process at high temperature and would have allow to increase the maximum adsorption level.

\subsection{Pore size diameter effect on the asphaltene diffusion process}

Figure 5 shows the evolution of the asphaltene content versus time up to 95 days for various alumina supports and for two different temperatures, $298 \mathrm{~K}$ and $523 \mathrm{~K}$. At $298 \mathrm{~K}$, the presence of some macroporosity (see figure 1) has a major effect on the maximum amount of asphaltenes deposited on the support in diffusion conditions. This maximum value is higher than the one expected from the adsorption experiments on M14 and the surfaces area of respectively M14 and B14 (see Table 3). Indeed, according to surface area saturation would have been reached at around $100 \mathrm{mg} / \mathrm{g}$ at $298 \mathrm{~K}$ and $140 \mathrm{mg} / \mathrm{g}$ at $523 \mathrm{~K}$ whereas B14 saturation concentration is 
measured closed to $230 \mathrm{mg} / \mathrm{g}$ without any influence of the temperature. Hence, the effect of macroporosity is major at room temperature. These large channels favor the flooding of the asphaltenic solution rather quickly. It confirms that M14 adsorption experiments are limited by the diffusion step, at least for $298 \mathrm{~K}$ experiments. Concerning the absence of change in saturation value comparing room temperature and high temperature experiment on B14, we can propose that for this support there is no diffusion limitation and the saturation value $230 \mathrm{mg} / \mathrm{g}$ is the intrinsic saturation of alumina as confirmed by the consistence of saturation value with the literature data $: 1.4 \mathrm{mg} / \mathrm{m}^{2}$ for B14.

For mesoporous supports (M9, M14, M17), we can observe that a rather small variation of the average size of the pore diameter can significantly influence the concentration on the support. According to the experimental errors, we clearly detect an increasing amount of the adsorbed concentration from M9 to M17 supports. These results suggest that the adapted size of the mesoporosity can favor the diffusion into the mesoporous network. It empathize the fact that diffusion restrictions override the variation of surface area. Indeed, compared to a maximum amount of asphaltenes adsorbed deduced of the available surface area estimated at $225 \mathrm{mg} / \mathrm{g}$ and $290 \mathrm{mg} / \mathrm{g}$ at 298 and $523 \mathrm{~K}$ respectively, the maximum uptake allowed to diffuse trough M9 alumina keeps really lower: about half of the expected value at the corresponding temperature $(80 \mathrm{mg} / \mathrm{g}$ at $298 \mathrm{~K}$ and $120 \mathrm{mg} / \mathrm{g}$ at $523 \mathrm{~K})$.

Nevertheless, the temperature effect is more sensitive for low contact times. We can see, on figure 5, that the time scale of the adsorption process is not equivalent; more or less $100 \mathrm{mg} / \mathrm{g}$ (of support) of asphaltenes can be adsorbed at $298 \mathrm{~K}$ into the carrier in one day when a rather more important amount $(140 \mathrm{mg} / \mathrm{g})$ of asphaltenic species is adsorbed in only 3 hours at $523 \mathrm{~K}$. This 
remarkable rise of the soaking with temperature is likely due to a disaggregation behavior and consequently a waning of the viscosity of the solution.

Figure 6 presents the radial profiles of the asphaltene penetration into the different supports, at $298 \mathrm{~K}$ and at $523 \mathrm{~K}$. For the three monomodal alumina, we can point out at:

- The great heterogeneity of the asphaltene repartition along the diameter at room temperature,

- The diameter sensitivity to the diffusion and adsorption process, the largest pore-size supports being progressively darker.

At a high temperature, the difference of color is less significant between the core and edges of extrudates even if the gradient of color (concentration) remains existing (not very well quantified by optical observations).

For the B14 support, a rather strange aspect is depicted for a room temperature experiment, characterized by three concentric rings:

- the first one, black at the periphery of the extrudate,

- an internal brownish ring,

- $\quad$ and the third one at the center, clear and quite free of asphaltenes.

We have tried to follow the evolution of these concentric rings versus time (figure 7). We observe a progressive browning of the central part of the extrudate as the contact time is increased. Around 54 days are needed to reach a rather homogeneous dark color. A similar behavior is observed at $523 \mathrm{~K}$ but faster than at ambient condition (figure 6 ). 
In order to clarify these observations we have suggested the following mechanism. At 298K, the size segregation of asphaltenes is already proved when mesoporous supports are used. When macropores are present (B14), we can suggest a rather quick penetration of the asphaltenic species, producing a kind of segregation between small and big asphaltenes:

- The first ones have a tendency to migrate quickly,

- when the second ones are delayed near the surface of the extrudate.

As the contact time goes up, the penetration of the smallest entities goes forward to the center of the extrudate, producing the brownish aspect of the initial clear halo. The largest asphaltene entities, characterized by a slow kinetics of diffusion, progressively move to the inside of the extrudate. For long contact times, we tend to a more or less homogeneous repartition as can be seen by optical microscopy (figure 7). As temperature increases, this segregation process is smoothed, giving rise to a swift homogeneous dark view of the section of the extrudate (figure 6).

\subsection{Effect of the initial asphaltene concentration}

It is well known that the surrounding concentration of the diffusing species has a linear and tremendous effect on the kinetics of diffusion through a porous system [46]. So, four different asphaltene concentrations in toluene (from 1 to $5 \mathrm{wt} \%$ ) were investigated at room and high temperatures. The $2 \mathrm{wt} \%$ concentration corresponds to the one already used in the previous section. Let's recall that the ratio mass of asphaltenes to mass of support was kept equal for all the surrounding concentration, i.e. the weight of alumina is adjusted to the total amount of asphaltenes engaged into the experiment $(360 \mathrm{mg} / \mathrm{g}$ - see section 2.1). Figure 8 shows the 
asphaltene content on the support (M14) versus time of contact for the various concentrations at 298K. Due to lack of precision in all the weighting, transfer and the step leading to build those curves, it appears that the values at 24 days could appear to be switched, especially between 3 and wt $5 \%$, but this is only due to less accuracy. That is why only the global tendency is discussed hereafter. If one take a look to the entire curve there is no crossing between curves. As expected, the increase of the initial asphaltene concentration causes an increase of the amount adsorbed on the support at saturation although the amount of asphaltenes reported to the weight of alumina is not modified. Taking into account the beginning of the experiment, i.e. the lowest contact time (24 hours), it is possible to assess a velocity expressed as the amount of asphaltenes adsorbed reported to the time (Table 4): in practice this velocity is the tangent to the origin of the curve. We can notice an increase of the kinetics of diffusion versus the initial asphaltene concentration, from $1.2 \mathrm{mg} \cdot \mathrm{g}^{-1} \cdot \mathrm{hr}^{-1}$ with $1 \mathrm{wt} \%$ to $1.8 \mathrm{mg} \cdot \mathrm{g}^{-1} \cdot \mathrm{hr}^{-1}$ so a relative increase of $50 \%$. At high temperature we did not report the entire curve because only the 3 hours contact time has been evaluated for every concentration.

Table 4 also reports the amount of asphaltenes on the support when a steady regime of diffusion is reached (after 46 days at $298 \mathrm{~K}$ or after 3 hours at $523 \mathrm{~K}$ ). At $298 \mathrm{~K}$, the concentration increases from 1 to $2 \mathrm{wt} \%$ and remains quite stable between 2 and $5 \mathrm{wt} \%$. The values are lower than the saturation level observed in adsorption experiment on crushed extrudates (Table $\mathbf{3}, 130$ $\mathrm{mg} / \mathrm{g})$. For a high temperature $(523 \mathrm{~K})$, a continuous and quite linear increase of the amount of asphaltenes deposited on the support is observed (see table 4). This behavior at room temperature was already seen by Tayakout et al.[33]. These observations could be the consequence of a clogging effect. As the concentration increases, the asphaltene solution becomes more viscous, peculiarly at low temperature [47]. For the high concentrations, a three-dimensional network can 
begin to extend itself in the solution [48], more or less connected, where the migration into the support porosity will be strongly delayed or even impossible. For high temperature condition, much smaller asphaltenic entities are present, inter-molecular interactions if there exist are weaker. Thus the diffusion process follows a linear behavior (see table 4) in agreement with theoretical models of diffusion, in the range of concentration we have explored. At higher concentration we can suppose that the asphaltenes concentration would have probably been closer of the saturation level (Table $3,170 \mathrm{mg} / \mathrm{g}$ ).

\subsection{Catalytic performances}

The various alumina supports were used to prepare catalysts (see section 2.1) the one being evaluated in hydrotreatment of residue containing high concentration in asphaltenes (see section 2.3). The catalytic results obtained in batch reactor evaluation with NiMoP-M14, NiMoP-M17, NiMoP-B14 are reported in Table 5. The distillation has been performed on every effluent. No change was observed according to the catalyst with $\chi_{813 \mathrm{~K}}{ }^{+}$close to $66 \mathrm{wt} \%$. So we do not report the quantification of fraction and conversion rates.

Concerning the mesopore diameter effect, on mesoporous supports, a significant effect is clearly observed for all the reaction considered and especially for HDAsC7 and HDV. This effect is obviously due to the improvement of the diffusional contribution (see section 3.3). Moreover, these results suggest that the adapted size of the mesoporosity override the decrease of surface area, the latest usually decreasing the catalytic metal dispersion. In addition, it can be noted that the gain is not very high, which could also be due to the fact that diffusion is not so much accelerated comparing to the case of NiMoP-B14 which exhibit macroporosity (see section 3.3). 
Indeed, the NiMoP-B14 catalyst exhibits the highest HDV and HDCCR rates and if we take into account the molybdenum loaded into the reactor, the catalyst even better than the NiMoPM14 catalyst without macroporosity for all the reaction considered. The activity constant has been estimated using the following equation :

$$
\mathrm{k}_{\mathrm{HDX}}=L H S V \times \frac{1}{n-1} \times \frac{1}{\left(X_{0}\right)^{n-1}} \times\left(\left(1-\%_{H D X}\right)^{n-1}-1\right) \quad \text { Equation } 4
$$

with :

- $\quad \mathrm{n}$ being the order of reaction being supposed equal to 1.2 even if no kinetic test was performed to assess this order.

- $\quad$ X being S, V, CCR or AsC7

- $\quad \mathrm{X}_{0}$ being the concentration into the feed.

- LHSV being an equivalent parameter calculated as the ratio between the feed volume and the catalyst volume divided by the duration of the test :

$$
\mathrm{V}_{\text {feed }} /\left(\mathrm{V}_{\text {catalyst }} * \text { Time }\right) \quad \text { Equation } \mathbf{5}
$$

The NiMoP-B14 activity constant do not exceed the other catalysts for the various reactions, and only exceeds NiMoP-M14 for HDV and HDA but after correction with the molybdenum amount that is really lower for NiMoP-B14 due to the weak density of loading, it becomes the best catalyst for all the reactions reaching $50 \%$ of gain for HDAsC7 and $40 \%$ in HDV (Table 6). Even if the quantity of carriers evaluated is too weak, an increasing trend starts to be obtained when plotting the HDV activity versus the asphaltenes uptake deduced from the lab set up and would 
need to be completed (Figure 9). Those results emphasize the role of support in hydrotreating reaction and clearly confirm that the textural properties need to be carefully monitored to diminish the diffusional effect on catalytic performances.

\section{CONCLUSION}

This work offers a significant contribution to the investigation of the process of diffusion and adsorption of asphaltene species into the pore network of industrial supports of catalysts used for hydrotreatments and the influence on the catalytic behavior for hydrodesulfurization and hydrodemetallization of heavy feeds like residues. This process was followed at room temperature but also at relatively higher temperature (523K), close to the one industrially used. Our results have shown that, even at high temperature, the diffusion of asphaltenes is very slow; several days are needed in order to get access to the center of the extrudate. This low speed of diffusion is mainly due to the sizes of the asphaltene macromolecules but also to the strong affinity of the entities for the alumina support. We have not been able to estimate the saturation of carrier without diffusion restriction and it should be interesting to perform additional experiments of diffusion and adsorption on much smaller grains of alumina $(<100 \mu \mathrm{m})$, peculiarly for the determination of the maximum amount of asphaltenes having access to the alumina porosity. Nevertheless the results obtained show that only the extrudates of macroporous support might be likely to adsorb till its chemical saturation, i.e. an asphaltene content equal to $1.4 \mathrm{mg} / \mathrm{m}^{2}$ consistent with previous publications for those species.

Our results can be explained proposing an effect of multi-scale aggregation of asphaltenes. At $298 \mathrm{~K}$ the aggregation induces a segregation phenomenon similar to a filtration process, where the smallest compounds can easily enter inside the support porosity and diffuse rather quickly, 
while the heaviest compounds like aggregated ones are blocked at the periphery of the extrudate as observed by optical microscopy. At $523 \mathrm{~K}$, the largest asphaltenic species (mainly clusters) are broken into smaller aggregates. More asphaltenes with a size adapted to the average pore diameter of the support are present in the solution. As a consequence the driving force is higher and consequently the diffusion rate goes up and the final concentration reached is tremendously increased. Those conclusions are also supported by the drastic decrease of the porosity as the for a high asphaltene coverage onto the carrier. The pore clogging could be clarified when the asphaltene concentration of the initial solution reaches high values and the solution becomes highly viscous, i.e. over $5 \mathrm{wt} \%$.

To complete that work, catalytic test have been carried out in real operating conditions using real feed containing asphaltenes. It is clearly shown that the carrier that exhibit the fastest diffusion of asphaltenes through its porosity also exceeds the other one for catalytic performances (HDAsC7, HDV, HDS and HDCCR). NiMoP-B14 is the best catalyst for all the reactions reaching $50 \%$ of gain for $\mathrm{HDAsC} 7$ and $40 \%$ in $\mathrm{HDV}$. It highlights a clear link is here established between catalytic performances and diffusion and could be usefull for designing the best carriers to be used in heavy feed hydroprocessing. It could be completed with more support and catalytic nature different into the future to evaluate more precisely the contribution of diffusion and adsorption into the real catalytic process.

\section{ACKNOWLEDGMENTS}


The Laboratory of Textural and Mechanical Characterization of the IFPEn is thanked for its help and expertise on the porosity characterization of various supports to achieve this work.

\section{REFERENCES}

[1] Speight, J.G., 1999. The Chemistry and Technology of Petroleum. New York.

[2] J. Murgich, Molecular Simulation, 29 (2003), pp. 451-461

[3] H. Groenzin, O.C. Mullins, Energy \& Fuels, 14 (2000), pp. 677-684

[4] E.Y. Sheu, Energy \& Fuels, 16 (2002), pp. 74-82

[5] D. Fenistein, Loïc Barré, Daniel Broseta, Didier Espinat, Armand Livet, Jean-Noël Roux, Marco Scarsella, Langmuir, 14 (1998), pp. 1013-1020

[6] O.C. Mullins, H. Sabbah, J. Eyssautier, A.E. Pomerantz, L. Barré, A.B. Andrews, Y. RuizMorales, F. Mostowfi, R. McFarlane, L. Goual, R. Lepkowicz, T. Cooper, J. Orbulescu, R.M. Leblanc, J. Edwards, R.N. Zare, Energy Fuels 26 (2012) 3986-4003

[7] Structures and Dynamics of Asphaltenes; Mullins, O. C., Sheu, E. Y., Eds.; Plenum Press: New York, 1998. 
[8] Asphaltenes, Heavy Oils, and Petroleomics; Mullins, O. C., Sheu, E. Y., Hammami, A., Marshall, A. G., Eds.; Springer; New York, 2007.

[9] A.V. Pashigreva, G.A. Bukhtiyarova, O.V. Klimov, Y.A. Chesalov, G.S. Litvak, A.S.

Noskov, Catal. Today 149 (2010) 19-27

[10] E. Payen, D. Guillaume, C. Lamonier, K. Marchand, Method of preparing at least one cobalt and/or nickel salt of at least one Anderson's heteropolyanion combining molybdenum and cobalt or nickel in its structure. European Patent 1892038 A1, February 27, 2008

[11] J. Escobar, J.A. Toledo, A.W. Gutiérrez, M.C. Barrera, M.A. Cortés, C. Angeles, L. Díaz, Stud. Sur. Sc. Catal., 175 (2010) 767-770

[12] M.A. Lélias, P.J. Kooyman, L. Mariey, L. Oliviero, A. Travert, J. van Gestel, J.A.R. van Veen, F. Maugé, J. Catal., 267(1) (2009) 14-23

[13] P. Mazoyer-Galliou, C. Geantet, F. Diehl, C. Pichon, T.S. Nguyen, M. Lacroix, Oil\&Gas Sci.Tech.- Rev. IFP, 60(5) (2005) 791-799

[14] T. S. Nguyen, S. Loridant, C. Lorentz, T. Cholley, C. Geantet, Appl. Catal. B 107(1-2) (2011) 59-67

[15] M.S. Rana, J. Ramirez, A. Guttierez-Alejandre, J. Ancheyta, L. Cedeno, S.K. Maity, J. Catal., 246 (2007) 100-108

[16] J. Escobar, M.C. Barrera, J.A. Toledo, M.A. Cortés-Jacome, C.A. Chavez, A. Nunez, V. Santes, E. Gomez, L. Diaz, E. Romero, J.G. Pacheco, Appl. Catal. B, 88 (2009) 564-575 
[17] V. Costa, K. Marchand, M. Digne, C. Geantet, Catal. Today, 130(1) (2008) 69-74

[18] Merdrignac, I.; Espinat, D.; Hénaut, I.; Argillier, J. F. Properties and Composition. In Heavy Crude Oils - from Geology to Upgrading - An Overview; Huc A. Y., Eds.; Editions Technip: Paris, 2011; Chapter 4, p. 34.

[19] J.F. Le Page, S.G. Chatila, M. Davidson, Raffinage et conversion des produits lourds du pétrole, Technip (1990)

[20] Guillaume Magendie, Bertrand Guichard, Didier Espinat, Catal. Today, 258(2) (2015) $304-318$

[21] Catalysis by transition metal sulphides - From Molecular Theory to Industrial Application; Toulhoat, H., Raybaud, P., Eds.; Editions Technip: Paris, 2013.

[22] Maity, S. K.; Pérez, V. H. ; Ancheyta, J. ; Mohan S. Rana Energy Fuels, 21 (2007) 636639

[23] Espinat, D.; Fenistein, D.; Barre, L.; Frot, D.; Briolant, Y. Energy Fuels, 18 (2004) 12431249

[24] Plumail, J. C. ; Jacquin, Y. ;Martino, G. ; Toulhoat, H. « Symposium on Processing Heavy Oils and Residua », Seattle Meeting, March 20-25, 1983.

[25] Thrash, R. J.; Pildes, R. H. ACS Preprints, Division of Petroleum Chemistry 26(2) (1981) $515-525$

[26] Baltus, R. E.; Anderson, J. L. Chemical Engineering Science, 38(12) (1983) 1959-1969 
[27] Kyriacou, K. C.; Sivaramakrishna, V. V.; Baltus, R. E.; Rahimi, P. Fuel, 67 (1988) 15-18

[28] Sane, R. C. ; Tsotsis, T. T. ; Webster, I. A.; Ravi-Kumar, V. S. Chemical Engineering Science 1992, 47(9-11), 2683-2688

[29] Dechaine, G. P.; Gray, M. R. Energy Fuels, 25 (2011) 509-523

[30] Lee, S.Y., Seader, J.D., Tsai, C.H., Massoth, F.E.. Industrial \& Engineering Chemistry Research, 30 (1991) 1683-1693.

[31] Mieville, R. L. ; Trauth, D. M. ; Robinson, K. K. ACS Preprints, Division of Petroleum Chemistry, 34 (1989) 635-643

[32] Xiaofeng Yang; Guin, J. A. Chem. Eng. Comm., 166( 1998) 57-79

[33] Tayakout, M.; Ferreira, C.; Espinat, D.; Picon, S. A.; Sorbier, L.; Guillaume, D.; Guibard, I. Chemical Engineering Science, 65 (2010) 1571-1583

[34] Marchal, C., Abdessalem, E., Tayakout-Fayolle, M.; Uzio, D. Energy \& Fuels, 24 (2010) $4290-4300$

[35] Marques, J.; Guillaume, D., Merdrignac, I.; Espinat, D.; Barré, L.; Brunet, S. Oil \& Gas Science and Technology - Rev. IFP, 64(6) (2009) 795-806

[36] Marques, J., Merdrignac, I., Baudot, A., Barré, L., Guillaume, D., Espinat, D., Brunet, S. Oil \& Gas Science and Technology - Rev. IFP, 63(1) (2009) 139-149

[37] Roussi, L., Stihle, J., Geantet, C., Uzio, D., Tayakout-Fayolle, M. Fuel, 109 (2013) $167-$ 177 
[38] Absi-Halabi, M, Stanislaus, A., Al-Mughni, T., Khan, S., Qamra, A., Fuel, 74 (1995) $1211-1215$

[39] Gaulier, F., Barbier, J., Guichard, B., Levitz, P., Espinat, D. Energy Fuels, 29 (2015) $6250-6258$

[40] Ackerman, R. C.; Ginestra, J. M-R; Michel, C. G. US Patent 7790 652, 2010.

[41] J. Lynch, Analyse physico-chimique des catalyseurs industriels. Manuel pratique de caractérisation, Ed.Technip Paris, 2001.

[42] Acevedo, S.; Ranaudo, M. A.; Garcia, C.; Castillo, J.; Fernandez, A. Energy Fuels, 17(2) (2013) $257-261$

[43] Dubey S.T.; Waxman M.H. "Asphaltenes Adsorption and Desorption From Mineral Surfaces", SPE 18462, SPE International Symposium on Oilfield Chemistry, Houston, 1989, 51 62.

[44] Jouault, N.; Corvis, Y.; Cousin, F.; Jestin, J.; Barré, L. Langmuir, 25 (2009) 3991-3998

[45] Espinat, D.; Freund, E.; Dexpert, H.; Martino, G. J. Catal., 126 (1990) 496-518

[46] Crank, J.; "The Mathematics of Diffusion", Second Edition, Clarendon Press - Oxford, 1975.

[47] Eyssautier, J.; Hénault, I.; Levitz, P.; Espinat, D. ; Barré, L. Energy Fuels, 26 (2012) 2696-2704 
[48] Espinat, D. ; Rosenberg, E. ; Scarsella, M. ; Barré, L., Fenistein, D., broseta, D. «Colloidal structural evolution from strable to flocculated state of asphaltene solutions and heavy crudes », in Structures and Dynamics of asphaltenes, edited by O. C. Mullins and E. Y. Sheu, Plenum Press - New York, 1998, 145-201. 
Table 1: Alumina carrier used in this work and main textural properties

\begin{tabular}{|c|c|c|c|c|c|}
\hline METHODS & DATAS & M9 & M14 & M17 & B14 \\
\hline \multirow{6}{*}{$\begin{array}{l}\text { Mercury } \\
\text { porosimetry }\end{array}$} & Pore Volume $\mathrm{mL} / \mathrm{g}$ & $0.69+/-0,06$ & $0.68+/-0.03$ & $0.66+/-0.03$ & $0,59+/-0.03$ \\
\hline & Macroporous volume, $\mathrm{mL} / \mathrm{g}$ & $<0.02$ & $<0.02$ & $<0.02$ & $0,35+/-0.02$ \\
\hline & MPD mesopores nm & $8.9+/-0.4$ & $13.7+/-0.7$ & $16.4+/-0.8$ & $13.3+/-0.7$ \\
\hline & MPD macropores nm & - & - & - & $820+/-40$ \\
\hline & Porosity $\%$ & $66+/-3$ & $69+/-3$ & $70+/-4$ & $75+/-4$ \\
\hline & Structural density, $\mathrm{g} / \mathrm{mL}$ & $2.59+/-0.26$ & $3.01+/-0.35$ & $3.20+/-0.32$ & $3.05+/-0.31$ \\
\hline \multirow{4}{*}{$\begin{array}{l}\text { Nitrogen } \\
\text { isotherm }\end{array}$} & BET Area m²/g & $340+/-20$ & $200+/-20$ & $150+/-10$ & $165+/-10$ \\
\hline & C parameter $(\mathrm{BET})$ & $99+/-8$ & $107+/-6$ & $115+/-6$ & $98+/-5$ \\
\hline & BJH volume $\mathrm{mL} / \mathrm{g}$ & $0.82+/-0.04$ & $0.80+/-0.04$ & $0.78+/-0.04$ & $0.72+/-0.04$ \\
\hline & MPD nm & $8.2+/-0.4$ & $13.5+/-1.3$ & $16.9+/-0.8$ & $14.3+/-0.7$ \\
\hline
\end{tabular}


Table 2. Characterization of Safaniya VR feedstock.

\begin{tabular}{|c|c|c|c|}
\hline & & & $\begin{array}{c}\text { Safaniya VR } \\
\text { feedstock }\end{array}$ \\
\hline \multirow[t]{3}{*}{ Global Analysis } & Density at $15^{\circ} \mathrm{C}$ & $\left(\right.$ g. $\left.\mathrm{cm}^{3}\right)$ & 1.0240 \\
\hline & API gravity & $\left({ }^{\circ} \mathrm{API}\right)$ & 6.186 \\
\hline & $\begin{array}{l}\text { Conradson } \\
\text { carbon }\end{array}$ & (wt.\%) & 21.6 \\
\hline \multirow[t]{4}{*}{ Elemental Analysis } & $\mathrm{Ni}$ & (wt. ppm) & 52 \\
\hline & $\mathrm{V}$ & (wt. ppm) & 164 \\
\hline & $\mathrm{S}$ & (wt.\%) & 5.10 \\
\hline & $\mathrm{N}$ & (wt.\%) & 0.40 \\
\hline \multirow[t]{4}{*}{ SARA Fraction } & Saturates & (wt.\%) & 10 \\
\hline & Aromatics & (wt.\%) & 40 \\
\hline & Resins & (wt.\%) & 36 \\
\hline & Asphaltenes $\mathrm{C}_{7}$ & (wt.\%) & 13 \\
\hline \multirow{5}{*}{$\begin{array}{l}\text { Simulated distillation } \\
\text { fractions }\end{array}$} & $643 \mathrm{~K}$ & (wt.\%) & 0 \\
\hline & $773 \mathrm{~K}$ & (wt.\%) & 5 \\
\hline & $813 \mathrm{~K}$ & (wt.\%) & 18 \\
\hline & $833 \mathrm{~K}$ & (wt.\%) & 25 \\
\hline & $853 \mathrm{~K}$ & (wt.\%) & 33 \\
\hline
\end{tabular}


Table 3. Estimation of the maximum amount that can be adsorbed on the various alumina carriers

\begin{tabular}{lcccc}
\hline & M9 & M14 & M17 & B14 \\
\hline BET Area $\mathrm{m}^{2} / \mathrm{g}$ & 340 & 200 & 150 & 165 \\
\hline Saturation at 298K (mg/g) & $225+/-20$ & $130+/-10$ & $100+/-10$ & $110+/-10$ \\
Saturation at 523K (mg/g) & $290+/-20$ & $170+/-10$ & $130+/-10$ & $140+/-10$ \\
\hline
\end{tabular}


Table 4. Evolution of the asphaltene concentration on the alumina support (M14) as a function of the initial asphaltene concentration of the surrounding solution (at 298K and at 523K) - Estimation of the initial speed of diffusion and adsorption of asphaltenes.

\begin{tabular}{|c|c|c|c|}
\hline $\begin{array}{c}\text { Initial } \\
\text { asphaltene } \\
\text { concentration }\end{array}$ & $\begin{array}{c}\text { Initial speed of } \\
\text { asphaltene transport } \\
\mathbf{m g} / \mathbf{g} / \mathbf{h r}\end{array}$ & $\begin{array}{c}\text { Asphaltene } \\
\text { concentration on the } \\
\text { support (after 46 } \\
\text { days at 298K - } \\
\mathbf{m g} / \mathbf{g})\end{array}$ & $\begin{array}{c}\text { Asphaltene } \\
\text { concentration on the } \\
\text { support (523K after 3 } \\
\text { hours of contact time } \\
- \\
\mathbf{m g} / \mathbf{g})\end{array}$ \\
\hline $\mathbf{1} \mathbf{w t \%}$ & $1,2_{+/-0,6}$ & $67_{+/-16}$ & $91_{+/-28}$ \\
\hline $\mathbf{2} \mathbf{w t \%}$ & $1,5_{+/-0,5}$ & $90_{+/-8}$ & $84_{+/-14}$ \\
\hline $\mathbf{3} \mathbf{w t \%}$ & $1,8_{+/-0,3}$ & $87_{+/-6}$ & $102_{+/-10}$ \\
\hline $\mathbf{5} \mathbf{w t \%}$ & $1,8_{+/-0,3}$ & $87_{+/-4}$ & $144_{+/-6}$ \\
\hline
\end{tabular}


Table 5. Catalytic results obtained with NiMoP-M14, NiMoP-M17, NiMoP-B14

\begin{tabular}{|c|c|c|c|c|c|}
\hline Catalyst & $\begin{array}{c}\text { Density of } \\
\text { loading (g.cm } \\
\mathbf{3} \text { ) }\end{array}$ & $\begin{array}{c}\text { AsC7 wt\% } \\
\text { (HDAsC7) }\end{array}$ & $\begin{array}{c}\text { S wt\% } \\
\text { (HDS) }\end{array}$ & $\begin{array}{c}\text { V ppm wt } \\
\text { (HDV) }\end{array}$ & $\begin{array}{c}\text { CCR wt\% } \\
\text { (HDCCR) }\end{array}$ \\
\hline feed & - & $12.7 \pm 0.4$ & $5.11 \pm 0.10$ & $166 \pm 7$ & $21.6 \pm 1.0$ \\
\hline NiMoP-M14 & 0.58 & $\begin{array}{c}5.9 \pm 0.3 \\
(56 \%)\end{array}$ & $\begin{array}{c}1.54 \pm 0.05 \\
(71 \%)\end{array}$ & $\begin{array}{c}53 \pm 4 \\
(70 \%)\end{array}$ & $\begin{array}{c}10.7 \pm 0.5 \\
(53 \%)\end{array}$ \\
\hline NiMoP-M17 & 0.59 & $\begin{array}{c}4.3 \pm 0.3 \\
(68 \%)\end{array}$ & $\begin{array}{c}1.44 \pm 0.05 \\
(73 \%)\end{array}$ & $\begin{array}{c}43 \pm 4 \\
(75 \%)\end{array}$ & $\begin{array}{c}9.3 \pm 0.5 \\
(55 \%)\end{array}$ \\
\hline NiMoP-B14 & 0.50 & $\begin{array}{c}4.8 \pm 0.3 \\
(64 \%)\end{array}$ & $\begin{array}{c}1.65 \pm 0.05 \\
(70 \%)\end{array}$ & $\begin{array}{c}43 \pm 4 \\
(76 \%)\end{array}$ & $\begin{array}{c}10.3 \pm 0.5 \\
(59 \%)\end{array}$ \\
\hline
\end{tabular}


Table 6. Activity constant with NiMoP-M14, NiMoP-M17, NiMoP-B14

\begin{tabular}{|c|c|c|c|c|c|c|c|c|c|}
\hline \multirow{2}{*}{ Catalyst } & \multirow{2}{*}{$\begin{array}{c}\text { Density of } \\
\text { loading } \\
\text { (g.cm-3 }\end{array}$} & \multicolumn{2}{|c|}{ HDAsC7 } & \multicolumn{2}{|c|}{ HDS } & \multicolumn{2}{|c|}{ HDV } & \multicolumn{3}{c|}{ HDCCR } \\
\cline { 4 - 9 } & RVA & RMoA & RVA & RMoA & RVA & RMoA & RVA & RMoA \\
\hline $\begin{array}{c}\text { NiMoP- } \\
\text { M14 }\end{array}$ & 0.58 & $\mathbf{1 0 0}$ & 100 & $\mathbf{1 0 0}$ & 100 & $\mathbf{1 0 0}$ & 100 & $\mathbf{1 0 0}$ & 100 \\
\hline $\begin{array}{c}\text { NiMoP- } \\
\text { M17 }\end{array}$ & 0.59 & $\mathbf{1 4 5}$ & 141 & $\mathbf{1 0 7}$ & 104 & $\mathbf{1 2 2}$ & 119 & $\mathbf{1 2 2}$ & 119 \\
\hline $\begin{array}{c}\text { NiMoP- } \\
\text { B14 }\end{array}$ & 0.50 & $\mathbf{1 3 0}$ & 150 & $\mathbf{9 5}$ & 110 & $\mathbf{1 2 1}$ & 140 & $\mathbf{1 0 7}$ & 124 \\
\hline
\end{tabular}




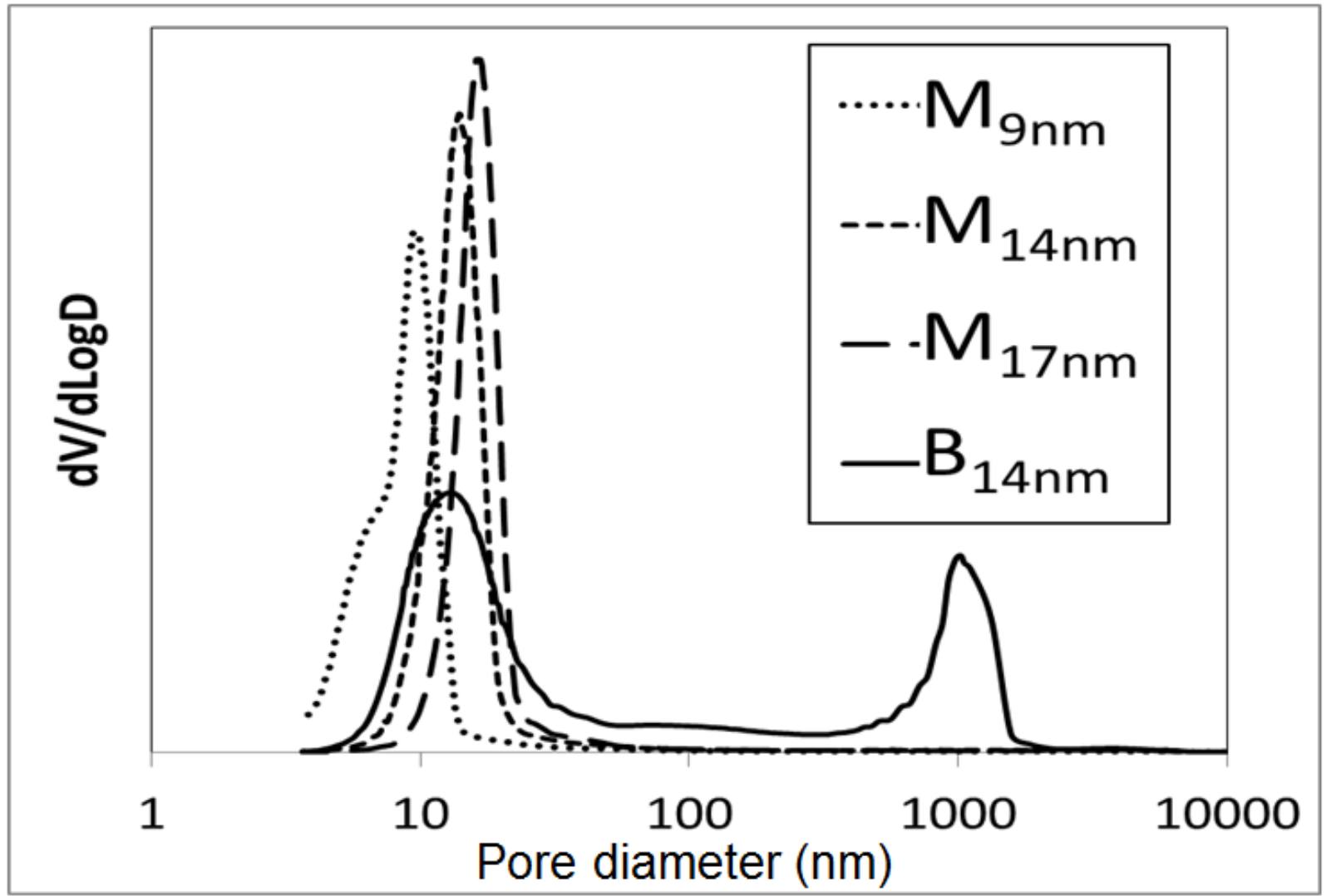

Figure 1. Pore size distributions obtained by mercury porosity technique for the alumina supports (M9, M14, M17, B14). 


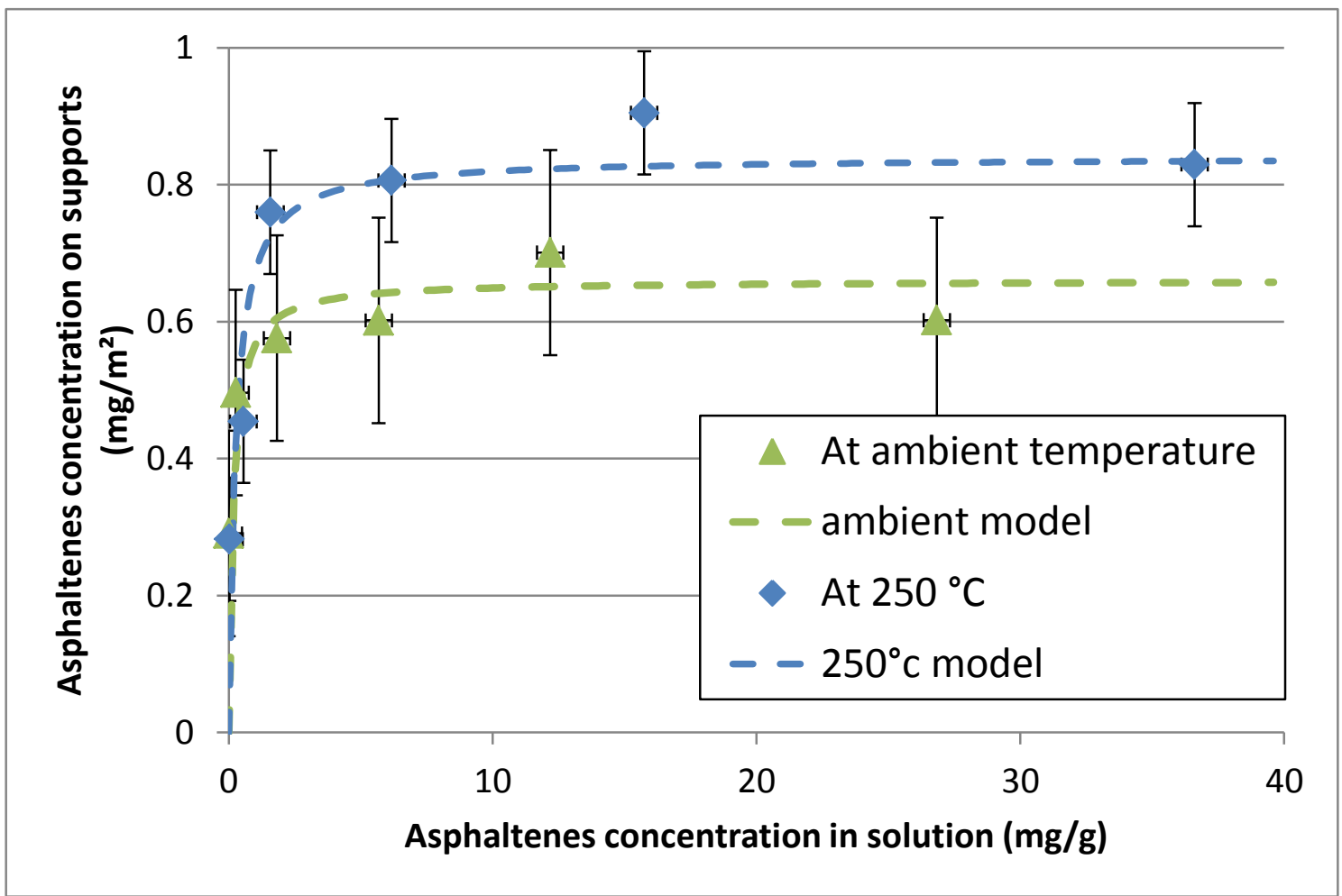

Figure 2. Repartition of asphaltenes at the equilibrium between the support (M9 - specific area: $340 \mathrm{~m}^{2} / \mathrm{g}$ ) and the asphaltene solution obtained at ambient temperature and at $523 \mathrm{~K}$. 
(a)

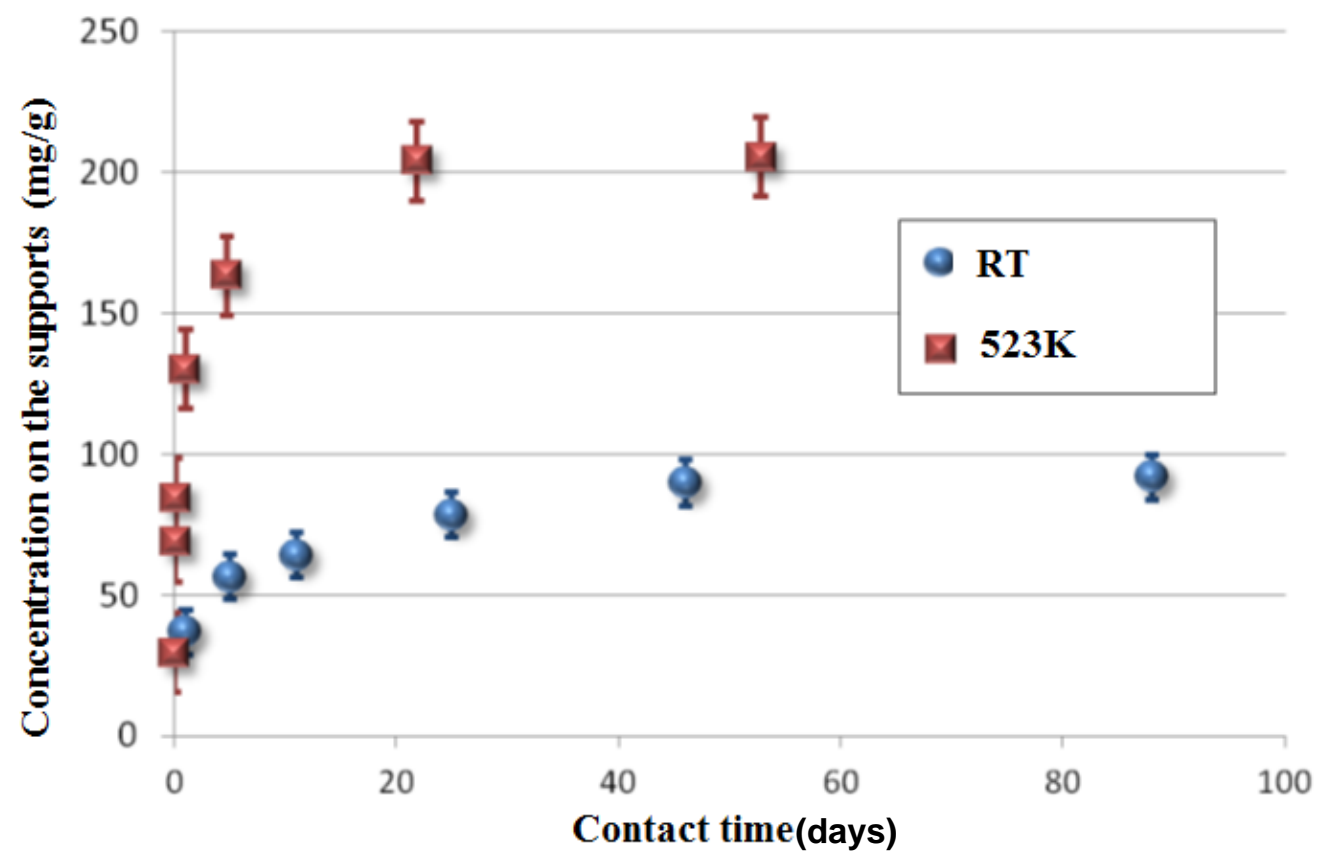

(b)

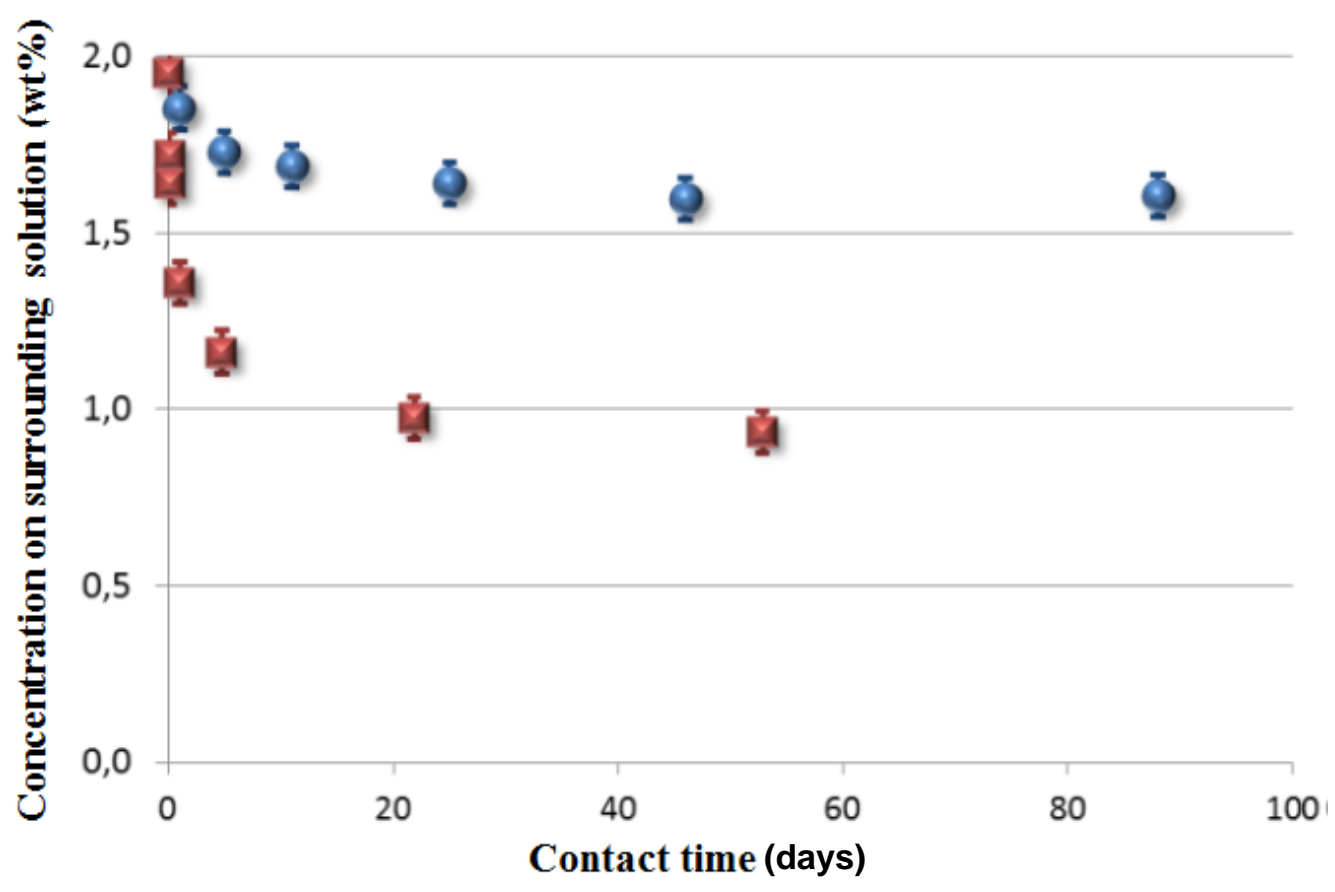

Figure 3. Evolution of the asphaltene concentration
(a) deposited on alumina on M14 at RT and 523K
(b) into the surrounding solution 


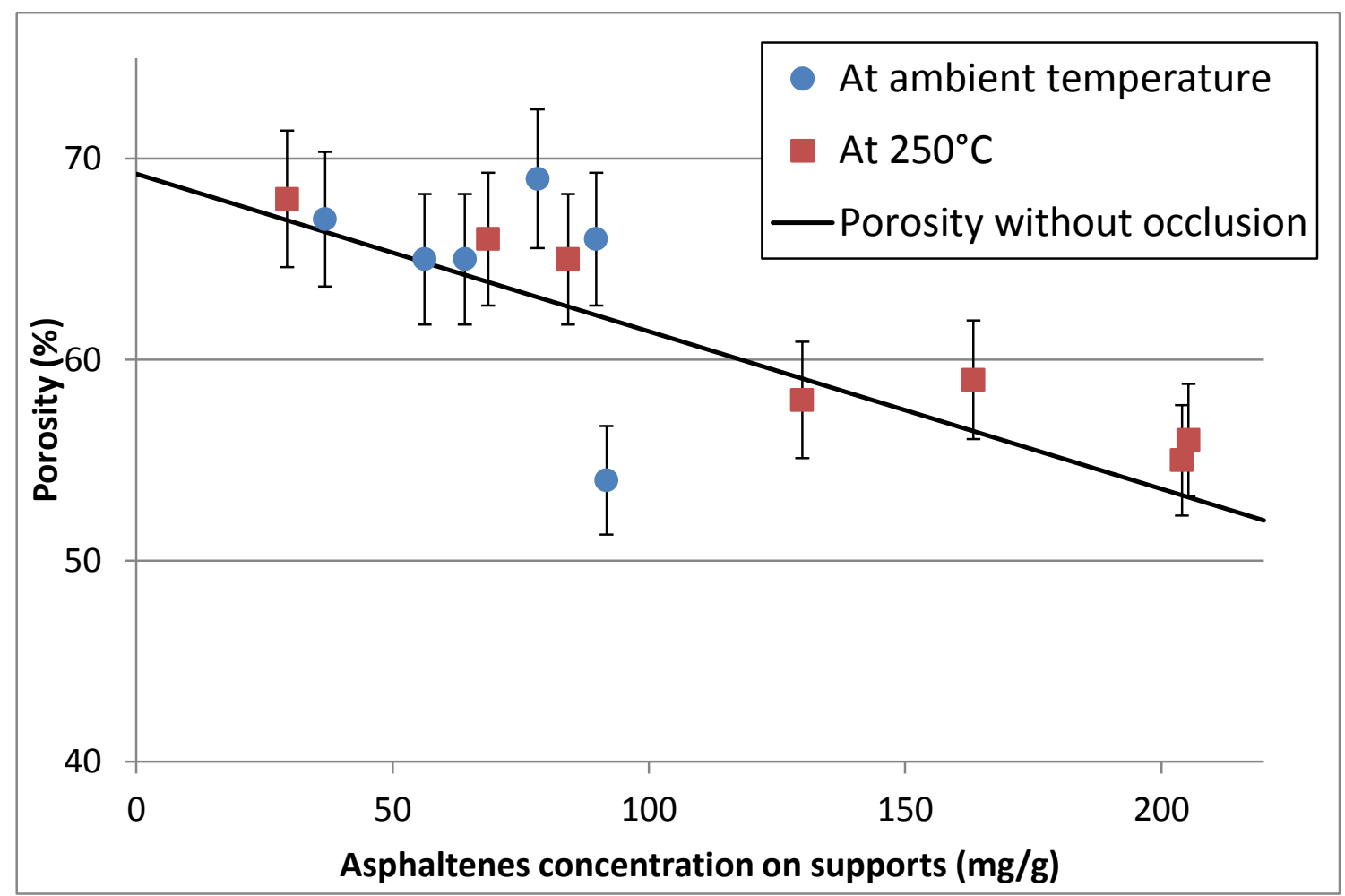

Figure 4. Evolution of the porosity of the M14 support, measured by nitrogen desorption, as a function of the asphaltenes concentration on the support, achieved at ambient temperature and at 523K. The straight line represents the theoretical evolution of the porosity (according to

\section{Equation 3)}


(a)

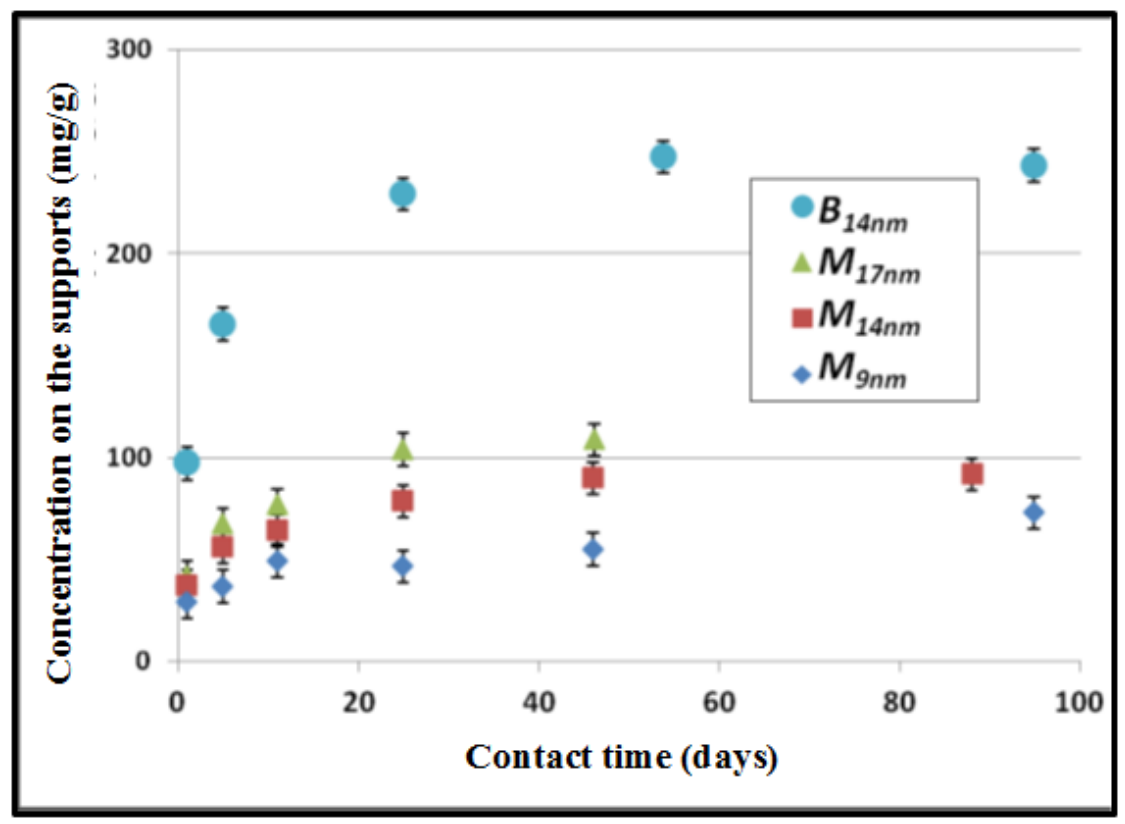

(b)

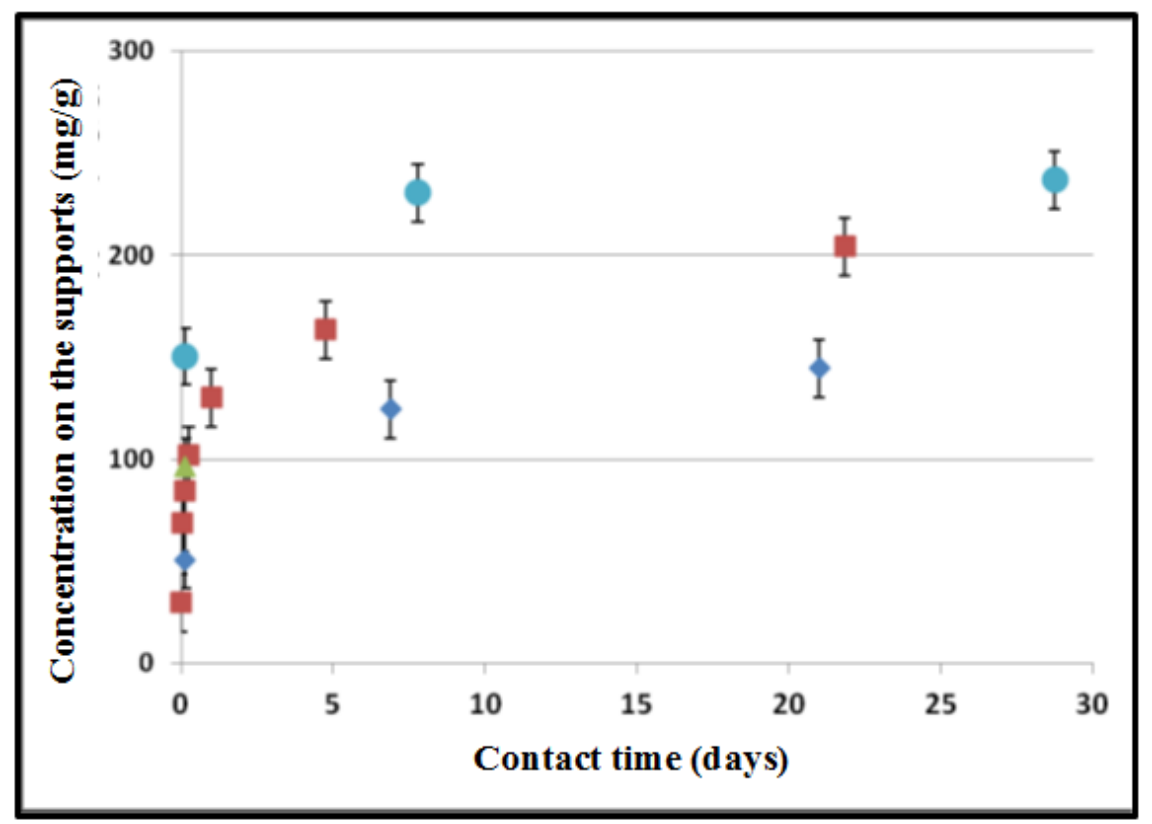

Figure 5. Evolution of the asphaltene concentration depending on textural properties of carriers: (a) at $298 \mathrm{~K}$, (b) at $523 \mathrm{~K}$ 


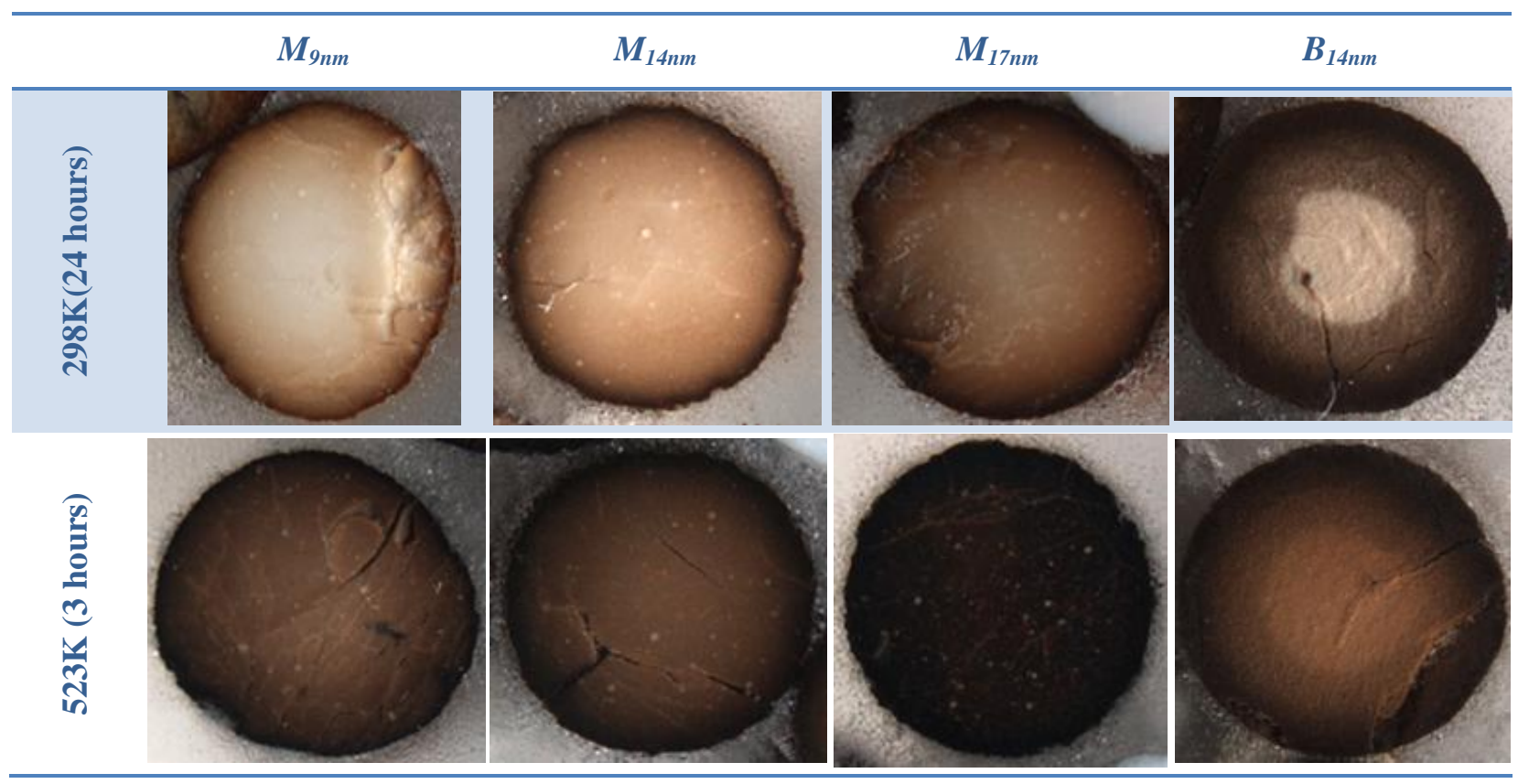

Figure 6. Asphaltene penetration into various alumina supports (M9, M14, M17, B14) followed by optical microscopy, at $298 \mathrm{~K}$ ( 24 hours) and at high temperature $(523 \mathrm{~K}-3$ hours). 

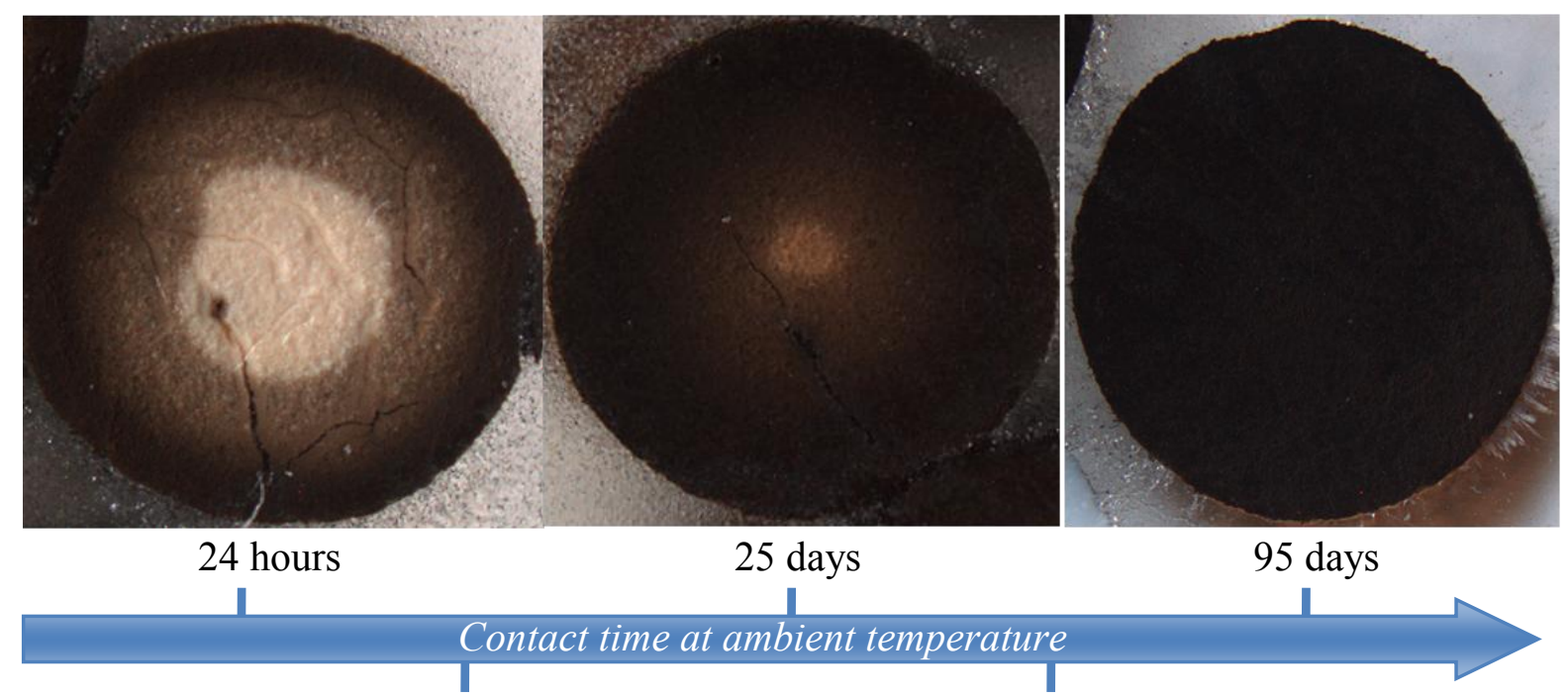

5 days

54 days
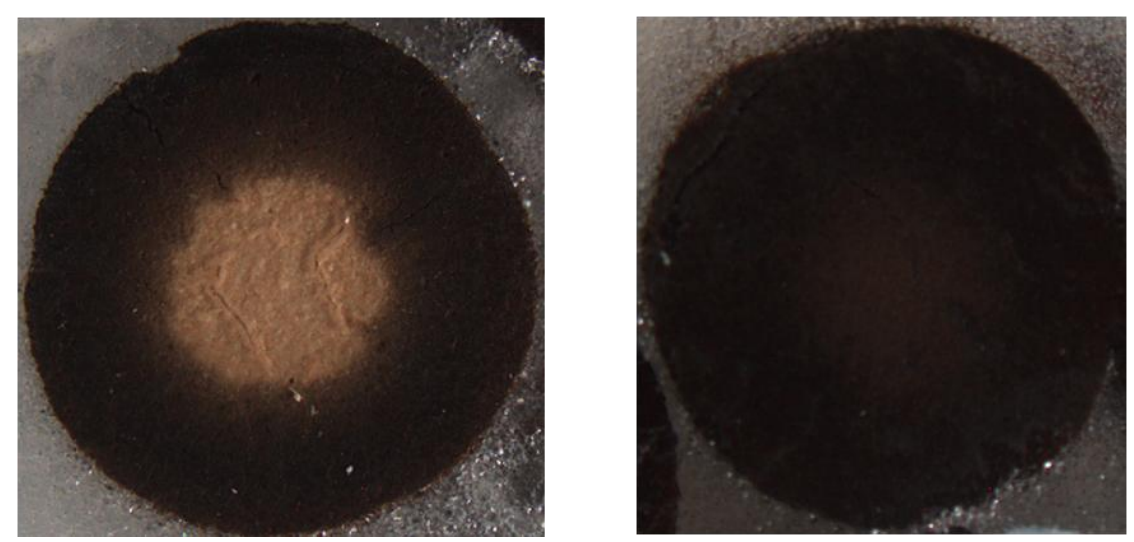

Figure 7. Observations by optical microscopy of extrudate sections of the B14 support soaked into asphaltene solution for different contact times and at room temperature. 


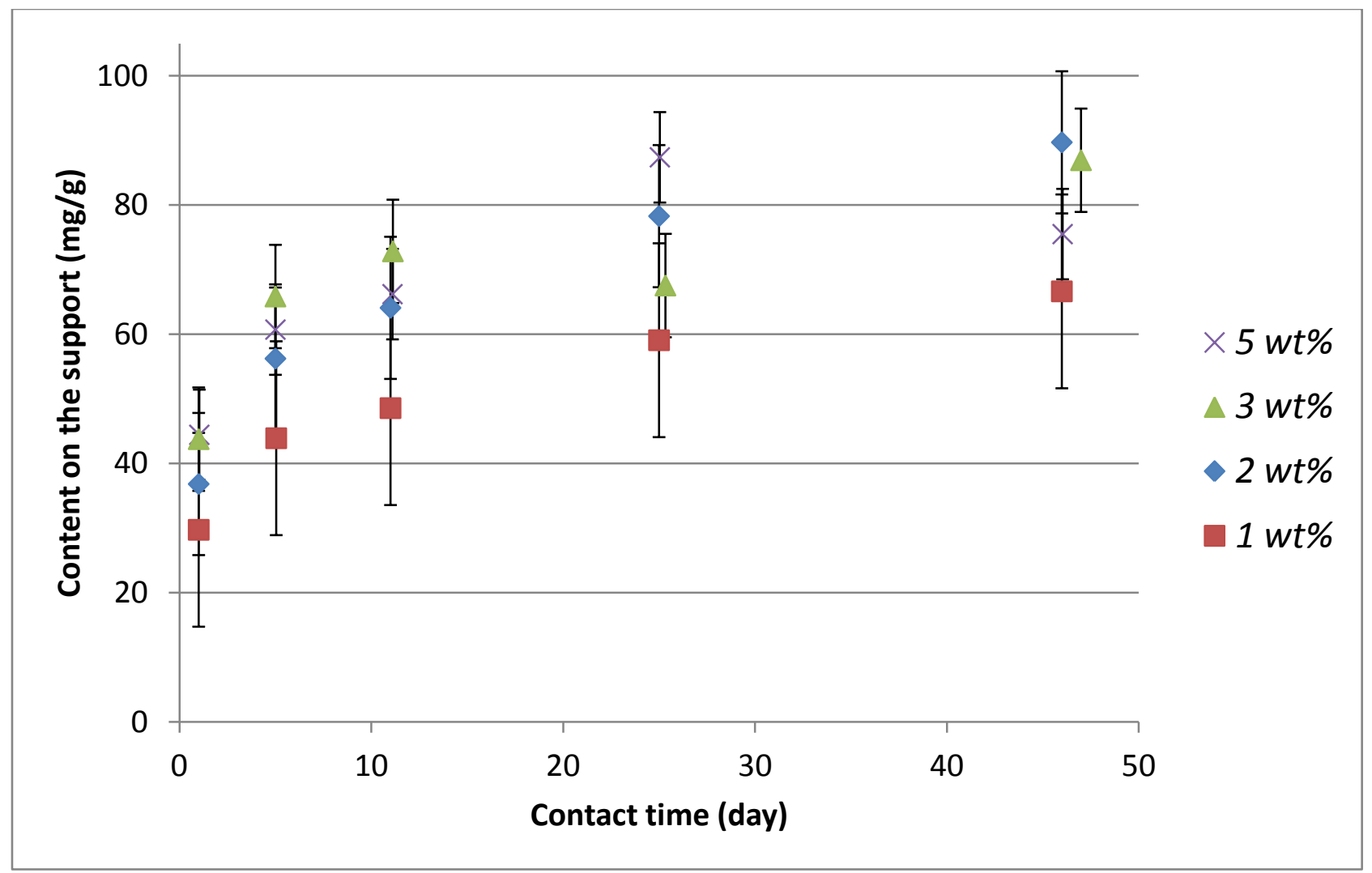

Figure 8. Evolution of the asphaltene content on the alumina support (M14) versus time, at $298 \mathrm{~K}$ and for various initial asphaltene concentrations of the surrounding solution 


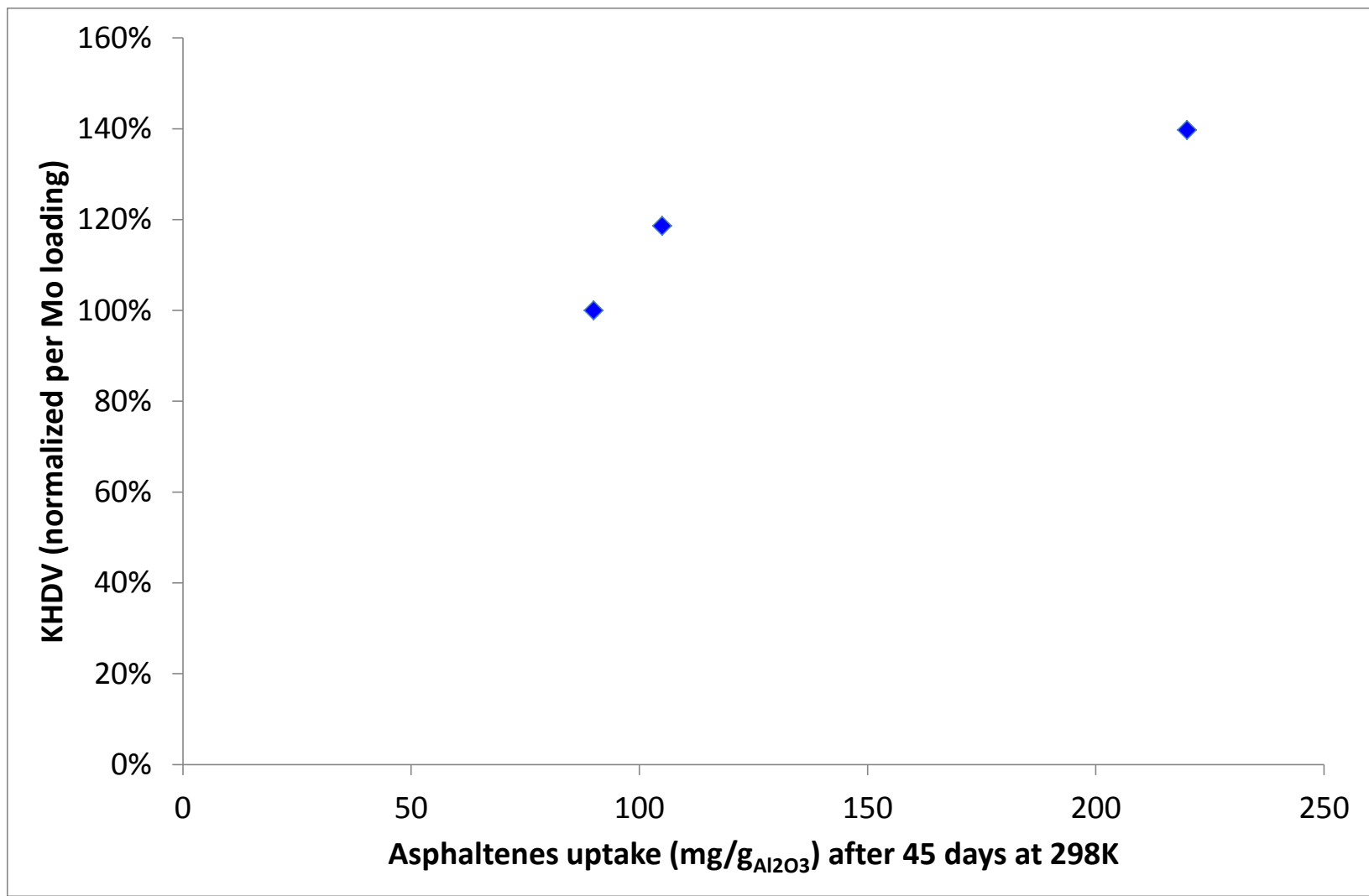

Figure 9. Evolution of HDV activity (see Table 6) versus the asphaltenes amount on carriers after diffusion experiments (see Figure 5a) 


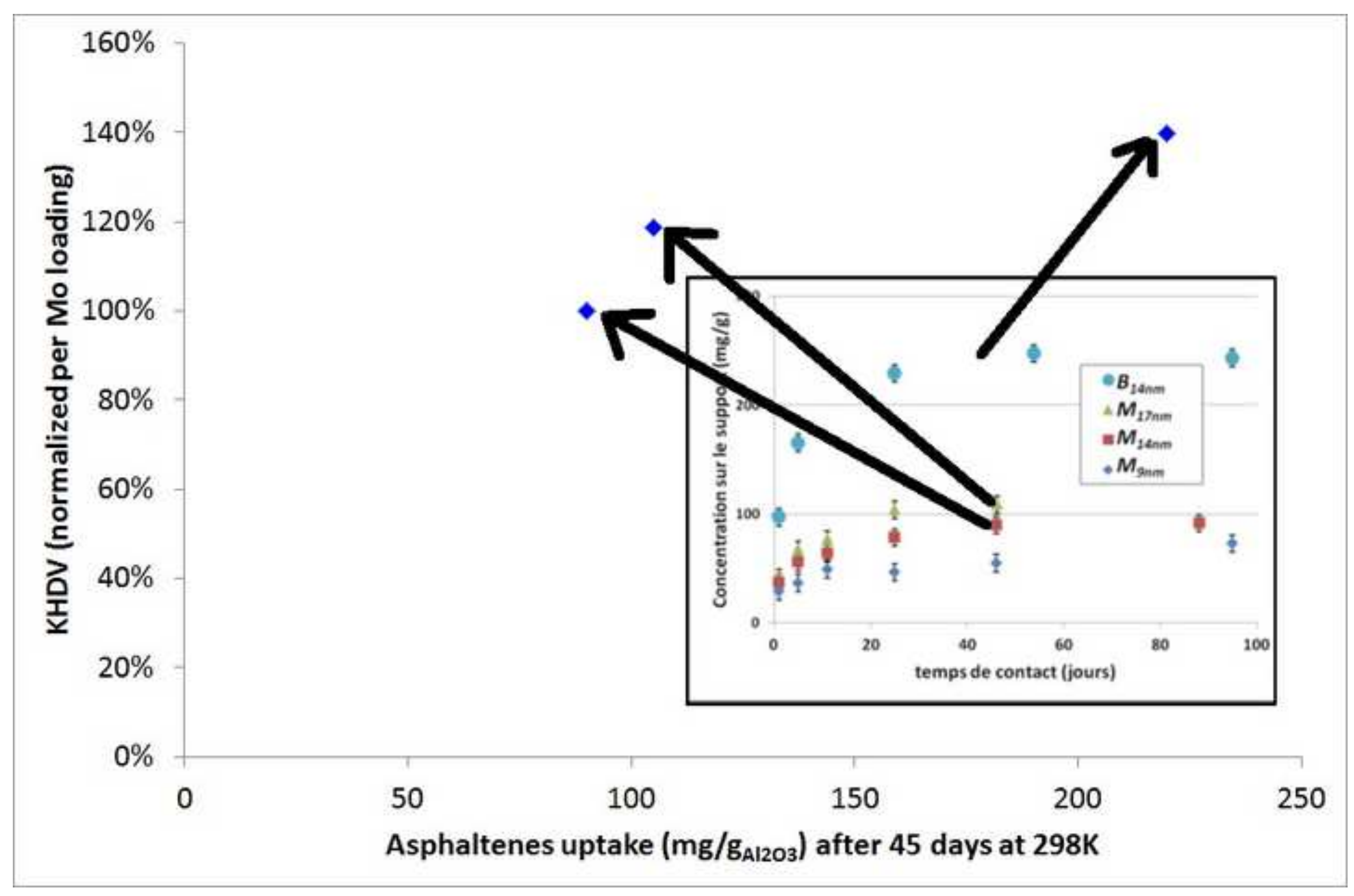

